\title{
PERANAN LABORATORIUM FORENSIK DALAM MENGUNGKAP TINDAK PIDANA PADA TINGKAT PENYIDIKAN
}

\author{
Andi Rachmad \\ Fakultas Hukum Universitas Samudra (Unsam) \\ Meurandeh Langsa Aceh \\ andrapunge@gmail.com
}

\begin{abstract}
Proof is the main thing in examining and prosecuting after the occurrence of a criminal case. This is because through the stages of proof there is a process, method, action proving to show the defendant's right or wrong against a criminal case especially in a court hearing. The role of the National Police Forensic Laboratory as an expert in its field in accordance with Article 7 paragraph (1) letter $h$ and Article 120 paragraph (1) Criminal Procedural Law (KUHAP) in the processing of crime scene with the application of scientific crime investigation (SCl) methods. Implementation of SCl / Criminalistic / Forensic in crime scene processing is a quality assurance and quality control. In implementing the crime scene, the implementation plays an important role in the process of creating a judge's conviction for the establishment of judicial decisions and is a legitimate proof that is irrefutable because it is based on scientific rules. Some obstacles faced by investigators in an effort to examine evidence against a crime are: the distance from the area to the remote Branch Forensic Laboratory, the limited operational costs of investigations and investigations, and the lack of required facilities and infrastructure.
\end{abstract}

Keywords: Forensic Laboratory, Crime, Investigation

\begin{abstract}
Abstrak, Pembuktian merupakan hal yang utama dalam pemeriksaan dan penindakan setelah terjadinya perkara pidana. Hal ini karena melalui tahapan pembuktian terjadi suatu proses, cara, perbuatan membuktikan untuk menunjukkan benar atau salahnya si terdakwa terhadap suatu perkara pidana khususnya di dalam sidang pengadilan. Peran Laboratorium Forensik Polri sebagai ahli di bidangnya sesuai Pasal 7 ayat (1) huruf $h$ dan Pasal 120 ayat (1) KUHAP dalam pengolahan Tempat Kejadian Perkara (TKP) dengan penerapan metode scientific crime investigation (SCl). Implementasi SCI/Kriminalistik/Forensik dalam olah TKP merupakan jaminan mutu (Quality Assurance) dan kendali mutu (Quality contro). Dalam pelaksanaan olah TKP, implementasi tersebut berperan penting terhadap proses menciptakan keyakinan hakim guna penetapan putusan peradilan dan merupakan alat bukti yang sah tidak terbantahkan karena berdasarkan kaidah-kaidah ilmiah. Beberapa hambatan yang dihadapi oleh penyidik dalam upaya pemeriksaan alat bukti terhadap tindak pidana yaitu: jarak lokasi dari daerah ke Labolatorium Forensik Cabang yang jauh, terbatasnya biaya operasional penyelidikan dan penyidikan, serta kurangnya jumlah sarana dan prasarana yang diperlukan.
\end{abstract}

Kata Kunci : Laboratorium Forensik, Tindak Pidana, Penyidikan

\section{Pendahuluan}

Penegakan hukum merupakan salah satu usaha untuk menciptakan tata tertib, keamanan dan ketentraman di dalam masyarakat, khususnya penindakan setelah 
terjadinya pelanggaran hukum. Pembuktian merupakan hal yang utama dalam pemeriksaan dan penindakan setelah terjadinya perkara pidana. Hal ini karena melalui tahapan pembuktian terjadi suatu proses, cara, perbuatan membuktikan untuk menunjukkan benar atau salahnya si terdakwa terhadap suatu perkara pidana khususnya di dalam sidang pengadilan.

Dalam menghadapi kasus tindak pidana yang tidak didukung dengan minimal dua alat bukti sah, aparat penegak hukum sulit membuktikan bersalah atau tidaknya tersangka/terdakwa. Pada zaman dahulu, apabila aparat penegak hukum menemukan kasus tindak pidana yang tidak didukung dengan alat bukti sah namun warga mencurigai atau menuduh seseorang sebagai pelaku tindak pidana tersebut, maka aparat penegak hukum akan mengutamakan pengakuan tersangka/terdakwa. Dalam mendapatkan alat bukti tersebut, aparat penegak hukum mengambil jalan pintas dengan melakukan penganiayaan dan penyiksaan kepada tersangka/terdakwa dengan memaksa untuk mengaku telah melakukan perbuatan pidana. ${ }^{1}$

Proses penyelidikan dan penyidikan tindak pidana pada masa sekarang telah banyak mengalami kemajuan dengan adanya perkembangan ilmu pengetahuan dan teknologi yang modern. Salah satu dampak perkembangan ilmu pengetahuan dan teknologi terhadap penyelidikan dan penyidikan tindak pidana adalah dengan dibangunnya laboratorium forensik.

Penjelasan mengenai laboratorium forensik Polri diatur pada Pasal 1 angka 2 Peraturan Kapolri Nomor 10 Tahun 2009 tentang Tata Cara dan Persyaratan Permintaan Pemeriksaan Teknis Kriminalistik Tempat Kejadian Perkara dan Laboratoris Kriminalistik Barang Bukti Kepada Laboratorium Forensik Kepolisian Negara Republik Indonesia, yang berbunyi:

"Laboratorium Forensik Polri adalah satuan kerja Polri meliputi Pusat Laboratorium Forensik dan Laboratorium Forensik Cabang yang bertugas membina dan menyelenggarakan fungsi laboratorium Forensik/Kriminalistik dalam rangka mendukung penyidikan yang dilakukan oleh Satuan Kewilayahan, dengan pembagian wilayah pelayanan (area service) sebagaimana ditentukan dengan Keputusan Kapolri.”

Laboratorium Forensik POLRI merupakan salah satu sarana untuk membantu penyelidikan dan penyidikan yang kewenangannya diatur dalam UU No. 8 Tahun 1981 tentang KUHAP. Peranan laboratorium forensik sangat penting dalam mengungkap kasus kejahatan melalui proses pemeriksaan barang bukti. Untuk dapat mengetahui dan dapat membantu proses penyidikan, maka dalam perkara pidana yang menyangkut tubuh, kesehatan dan nyawa manusia diperlukan pengetahuan khusus, yaitu ilmu kedokteran kehakiman (istilah lain sering dipakai: ilmu kedokteran forensik, forensic medicine, legal medicine dan medical jurisprudence). ${ }^{2}$

Kasus tindak pidana pada dasarnya memiliki 3 bukti segitiga (triangle evidence) yang merupakan sumber pembuktian untuk mengungkap tindak pidana, yaitu:

${ }^{1}$ Abdussalam, Buku Pintar Forensik (Pembuktian Ilmiah), (Jakarta: Restu Agung, 2006), hlm. 1

2 Abdul Mun'im Idries dan Agung Legowo Tjiptomartono, Penerapan Ilmu Kedokteran Kehakiman dalam Proses Penyidikan, (Jakarta: Karya Unipres, 1982), hlm. 1 
a. Tempat Kejadian Perkara (TKP), yaitu tempat kejadian perkara yang berupa tempat terjadinya kejahatan, pelanggaran, maupun kecelakaan lalu lintas dan merupakan bahan penting sebagai sumber penyidikan perkara pidana.

b. Korban adalah korban kejahatan merupakan orang yang dirugikan baik secara fisik maupun materi oleh pelaku kejahatan seperti korban manusia yang masih hidup atau meninggal dunia.

c. Barang bukti adalah bekas-bekas darah, alat yang dipakai pelaku / tersangka seperti kelongsong peluru, pisau atau sidik jari dan sebagainya. ${ }^{3}$

Oleh karena itu, tidak semua kejahatan dapat diketahui dan diungkap melalui keterangan saksi dan tersangka atau terdakwa saja, tetapi barang bukti juga dapat memberi petunjuk atau keterangan atas suatu tindak kejahatan yang telah terjadi. Hal ini karena hasil pemeriksaan barang bukti dari laboratorium forensik menghasilkan tiga alat bukti dari lima alat bukti yang sah berdasarkan Pasal 184 ayat (1) Undang-Undang Nomor 8 Tahun 1981 tentang Kitab Undang-Undang Hukum Acara Pidana (KUHAP) yaitu keterangan saksi, keterangan ahli, surat, dan petunjuk serta keterangan terdakwa.

Berdasarkan latar belakang di atas penulis tertarik untuk meneliti dan menuliskan hasilnya dalam skripsi berjudul "Peranan Laboratorium Forensik Dalam Mengungkap Tindak Pidana Pada Tingkat Penyidikan."

Berdasarkan latar belakang masalah di atas, maka dapat dirumuskan permasalahannya sebagai berikut :

1. Bagaimana peranan laboratorium forensik dalam upaya pemeriksaan alat bukti terhadap suatu tindak pidana?

2. Apa hambatan penyidik dalam pemeriksaan alat bukti terhadap tindak pidana?

\section{Metode Penulisan}

Penelitian ini menggunakan metode penelitian yuridis normatif oleh karena penelitian ini lebih bersifat penelitian pada data sekunder. Data sekunder dalam penelitian hukum normatif, meliputi :

1. Bahan hukum primer, yaitu bahan hukum yang mengikat yang terdiri dari Peraturan Perundang-undangan, berupa Kitab Undang-Undang Hukum Pidana (KUHP), Kitab Undang-Undang Hukum Acara Pidana (KUHAP), Peraturan Kapolri Nomor 10 Tahun 2009 tentang Tata Cara dan Persyaratan Permintaan Pemeriksaan Teknis Kriminalistik Tempat Kejadian Perkara dan Laboratoris Kriminalistik Barang Bukti Kepada Laboratorium Forensik Kepolisian Negara Republik Indonesia, Peraturan Kapolri Nomor 12 Tahun 2011 tentang Kedokteran Kepolisian dan bahan hukum primer lainnya yang berkaitan dengan obyek penelitian;

2. Bahan hukum sekunder, yang memberikan penjelasan mengenai bahan hukum primer, seperti hasil-hasil penelitian, hasil karya tulis dari kalangan hukum seperti literatur hukum pidana dan bahan hukum sekunder lainnya yang berkaitan dengan obyek penelitian;

${ }^{3}$ H.S. Brahmana, Kriminalistik dan Hukum Pembuktian, (Langsa: LKBH Fakultas Hukum Universitas Samudra, 2014), hlm. 18. 
3. Bahan hukum tertier, yaitu bahan hukum yang memberikan penjelasan terhadap bahan hukum primer dan sekunder, antara lain kamus, ensiklopedia, media elektronik dan sebagainya. ${ }^{4}$

\section{Pembahasan}

\section{A. Peranan Laboratorium Forensik Dalam Upaya Pemeriksaan Alat Bukti Terhadap Suatu Tindak Pidana}

Laboratorium di dalam Kamus besar bahasa indonesia diterjemahkan sebagai tempat atau kamar dan sebagainya tertentu yang dilengkapi dengan peralatan untuk mengadakan percobaan (penyelidikan dan sebagainya). ${ }^{5}$ Sedangkan forensik di dalam Kamus besar bahasa indonesia mempunyai dua arti, yaitu: ${ }^{6}$

a. Cabang ilmu kedokteran yang berhubungan dengan penerapan fakta medis pada masalah hukum.

b. Ilmu bedah yang berkaitan dengan penentuan identitas mayat seseorang yang ada kaitannya dengan kehakiman dan peradilan.

Bambang Widodo Umar mengatakan bahwa di dunia kepolisian, forensik sebagai cara dan alat bantu secara scientific untuk membuktikan atau mengungkap kasus-kasus untuk mendapatkan kebenaran yang sesungguhnya. ${ }^{7}$

Forensik (berasal dari bahasa Yunani 'Forensis' yang berarti debat atau perdebatan), yaitu bidang ilmu pengetahuan yang digunakan untuk membantu proses penegakan keadilan melalui proses penerapan ilmu (sains). Dalam kelompok ilmu-ilmu forensik dikenal antara lain ilmu fisika forensik, ilmu kimia forensik, ilmu psikologi forensik, ilmu kedokteran forensik, ilmu toksikologi forensik, komputer forensik, ilmu balistik forensik, ilmu metalurgi forensik dan sebagainya. ${ }^{8}$

Peran Laboratorium Forensik Polri sebagai ahli di bidangnya sesuai Pasal 7 ayat (1) huruf h dan Pasal 120 ayat (1) KUHAP dalam pengolahan Tempat Kejadian Perkara (TKP) dengan penerapan metode scientific crime investigation (SCI). ${ }^{9}$ Laboratorium Forensik memberikan pelayanan bagi penegak hukum serta masyarakat umum yang

\footnotetext{
${ }^{4}$ Sudarsono, Cara Penyelesaian Karya Ilmiah di Bidang Hukum, edisi revisi, (Yogyakarta: Mitra Kebijakan Tanah, 2006), hlm. 37

5 la.bo.ra.to.ri.um, https://kbbi.kemdikbud.go.id/entri/laboratorium, diakses tanggal 2 Februari 2017.

6 fo.ren.sik /forènsik/, https://kbbi.kemdikbud.go.id/entri/forensik, diakses tanggal 2 Februari 2017.

7 Forensik, Jalan untuk Mengungkap Kasus Pidana, http://www.hukumonline.com/berita/ baca/lt56bb21c48c5ea/forensik--jalan-untuk-mengungkap-kasus-pidana, diakses tanggal 2 Februari 2017

8 Apa Itu Ilmu Forensik? http://ondigitalforensics.weebly.com/digital-forensics/apa-itu-ilmuforensik\#.W6KBdUC4S_Q, diakses tanggal 2 Februari 2017

9 Teguh Prihmono, Umar Ma'ruf, dan Sri Endah Wahyuningsih, Peran Laboratorium Forensik Polri Sebagai Pendukung Penyidikan Secara Ilmiah Dalam Sistem Peradilan Pidana Di Indonesia, Jurnal Hukum Khaira Ummah, Vol. 13. No. 1 Maret 2018.
} 
memerlukan jasa pemeriksaan/pelayanan umum untuk mendapatkan rasa keadilan dan atau keperluan lainnya. Bidang yang menjadi tugas dari Labolatorium Forensik yaitu: ${ }^{10}$

a. Bidang Dokumen dan Uang Palsu Forensik (Biddokupalfor) yang bertugas menyelenggarakan pelayanan pemeriksaan teknis kriminalistik TKP dan pemeriksaan laboratoris kriminalistik barang bukti dokumen (tulisan tangan, tulisan ketik, dan tanda tangan), uang palsu (uang kertas RI, uang kertas asing, dan uang logam) dan produk cetak (produk cetak konvensional, produk cetak digital, dan cakram optik) serta memberikan pelayanan umum forensik kriminalistik.

b. Bidang Balistik dan Metalurgi Forensik (Bidbalmetfor) yang bertugas menyelenggarakan pelayanan pemeriksaan teknis kriminalistik TKP dan pemeriksaan laboratoris kriminalistik barang bukti senjata api (senjata api, peluru dan selongsong peluru), bahan peledak (bahan peledak, komponen-komponen bom, dan bom pasca ledakan (post blast) dan metalurgi (bukti nomor seri, kerusakan logam), dan kecelakaan konstruksi serta memberikan pelayanan umum forensik kriminalistik.

c. Bidang Fisika dan Komputer Forensik (Bidfiskomfor) yang bertugas menyelenggarakan pelayanan pemeriksaan teknis kriminalistik TKP dan pemeriksaan laboratoris kriminalistik barang bukti uji kebohongan (lie detector), jejak, radioaktif, konstruksi bangunan, peralatan teknik, kebakaran/pembakaran, dan komputer (suara dan gambar (audio/video), komputer dan telepon genggam (computer and mobile phones), dan kejahatan jaringan internet/intranet (cyber network) serta memberikan pelayanan umum forensik kriminalistik.

d. Bidang Kimia, Toksikologi, dan Biologi Forensik (Bidkimbiofor) yang bertugas menyelenggarakan pelayanan pemeriksaan teknis kriminalistik TKP dan laboratoris kriminalistik barang bukti kimia (bahan kimia yang belum diketahui (unknown material), dan bahan kimia produk industri), biologi/serologi (serologi, biologi molecular, dan bahan-bahan hayati) dan toksikologi atau lingkungan hidup (toksikologi, mikroorganisme, dan pencemaran lingkungan hidup), serta memberikan pelayanan umum forensik kriminalistik.

e. Bidang Narkotika, Psikotropika dan obat berbahaya forensik (Bidnarkobafor) yang bertugas menyelenggarakan pelayanan pemeriksaan teknis kriminalistik TKP dan pemeriksaan laboratoris kriminalistik barang bukti narkotika (narkotika bahan alam, bahan sintesa dan semi sintesa, dan cairan tubuh), psikotropika (bahan dan sediaan psikotropika, laboratorium illegal (clandestine labs) bahan psikotropika) dan obat (bahan kimia obat berbahaya, bahan kimia adiktif dan prekursor), serta memberikan pelayanan umum forensik kriminalistik.

Implementasi SCI/Kriminalistik/Forensik dalam olah TKP merupakan jaminan mutu (Quality Assurance) dan kendali mutu (Quality control). Dalam pelaksanaan olah TKP, implementasi tersebut berperan penting terhadap proses menciptakan keyakinan

10 Mengenal Laboratorium Forensik Bareskrim Polri, https://www.danielbachrul .com/2015/09/mengenal-laboratorium-forensik.htm, diakses tanggal 6 Mei 2018 
hakim guna penetapan putusan peradilan dan merupakan alat bukti yang sah tidak terbantahkan karena berdasarkan kaidah-kaidah ilmiah. ${ }^{11}$

Jika ditinjau dari praktik pelaksanaannya, maka peranan Laboratorium Forensik yaitu sebagai saksi ahli, diperlukan dalam setiap tahap pemeriksaan perkara yang erat tujuannya dengan upaya pembuktian perkara yang bersangkutan, dan pada akhirnya pembuktian tersebut harus dilakukan di depan persidangan. Dalam kaitannya dengan pembuktian perkara pidana, maka secara umum peranan keterangan ahli dapat diberikan dua bentuk, yang pertama adalah keterangan tertulis yang lazim disebut Visum et Repertum dan keterangan ahli (hasil penelitian laboratorium). ${ }^{12}$

Dokter dalam hal ini adalah dokter ahli Laboratorium Forensik dapat memberikan bantuannya dalam hubungannya dengan proses peradilan dalam hal: ${ }^{13}$

a. Pemeriksaan di tempat kejadian perkara. Pada umumnya diminta oleh penyidik atau pengadilan dalam hal mengungkap sebab-sebab terjadinya tindak pidana. Pemeriksaan oleh ahli forensik sangat penting dalam hal menentukan sebab-sebab terjadinya tindak pidana, dalam kaitan ini dokter akan membuat laporan berita acara pemeriksan laboratoris kriminalistik.

b. Pemeriksaan barang bukti

c. Memberikan kesaksian dalam sidang pengadilan, dalam hal ini apa yang diucapkan olehnya (ahli forensik) akan dikategorikan sebagai keterangan ahli). ${ }^{14}$

\section{B. Hambatan Penyidik Dalam Pemeriksaan Alat Bukti Terhadap Tindak Pidana}

Hukum acara pidana bertujuan untuk mencari kebenaran materil dari suatu peristiwa pidana. ${ }^{15}$ Dalam sistem peradilan pidana di Indonesia, penyidik merupakan organ pertama yang berkewajiban untuk membuktikan suatu tindak pidana. Kepolisian Republik Indonesia (POLRI) merupakan penyidik utama dalam hal adanya kemungkinan terjadinya tindak pidana umum. POLRI dalam hal menangani suatu kasus harus berpegang pada aturan hukum yang berlaku di Indonesia. Berdasarkan Pasal 1 angka 2 KUHAP, penyidikan adalah serangkaian tindakan penyidik dalam hal dan menurut cara yang diatur dalam Undang-undang untuk mencari serta mengumpulkan bukti yang dengan bukti itu membuat terang tentang tindak pidana yang terjadi dan guna menemukan tersangkanya.

\footnotetext{
${ }^{11}$ Teguh Prihmono, Umar Ma'ruf, dan Sri Endah Wahyuningsih, Peran Laboratorium Forensik Polri Sebagai Pendukung Penyidikan Secara Ilmiah Dalam Sistem Peradilan Pidana Di Indonesia, Jurnal Hukum Khaira Ummah, Vol. 13. No. 1 Maret 2018.

${ }_{12}$ Distty Rosa Permanasari Harry Tanto, Fungsi Dan Peran Laboratorium Forensik Dalam Mengungkap Sebab-Sebab Kematian Korban Tindak Pidana Pembunuhan (Studi Pada Laboratorium Forensik Cabang Semarang), Skripsi, Universitas Negeri Semarang, 2011, hlm. 67.

${ }^{13} \mathrm{Ibid}$, hlm. 67-68.

${ }^{14}$ Keterangan ahli diperlukan sebagaimana dirumuskan dalam Pasal 180 ayat (1) KUHAP yang berbunyi, "Dalam hal diperlukan untuk menjernihkan duduk persoalan yang timbul di sidang pengadilan, Hakim Ketua sidang dapat minta keterangan ahli dan dapat pula diajukan bahan baru oleh yang berkepentingan."

${ }^{15}$ Yulia Monita dan Dheny Wahyudhi, Peranan Dokter Forensik Dalam Pembuktian Perkara Pidana, https://media.neliti.com/media/publications/43243-ID-peranan-dokter-forensik-dalampembuktian-perkara-pidana.pdf, diakses tanggal 5 Mei 2018.
} 
Pasal 2A Peraturan Pemerintah Nomor 58 Tahun 2010 tentang Perubahan Atas Peraturan Pemerintah Nomor 27 Tahun 1983 tentang Pelaksanaan Kitab Undang-undang Hukum Acara pidana menyatakan bahwa, syarat menjadi penyidik yaitu:

a. Berpangkat paling rendah Inspektur Dua Polisi dan berpendidikan paling rendah sarjana strata satu atau yang setara;

b. Bertugas di bidang penyidikan paling singkat 2 (dua) tahun;

c. Mengikuti dan lulus pendidikan pengembangan spesialisasi fungsi reserse kriminal;

d. Sehat jasmani dan rohani yang dibuktikan dengan surat keterangan dokter;

e. Memiliki kemampuan dan integritas moral yang tinggi.

Peranan penyidik dalam upaya pemeriksaan alat bukti terhadap tindak pidana yaitu:

a. Untuk mencari dan mengumpulkan barang bukti

b. Untuk membuat terang suatu tindak pidana

Langkah awal dalam menangani tindak pidana, pihak kepolisian pada umumnya akan mengumpulkan informasi dari masyarakat dan melanjutkan dengan membuat laporan informasi untuk disampaikan kepada pimpinan. Setelah mendapat surat perintah, dilanjutkan dengan melakukan penangkapan, penggeledahan dan penyitaan terhadap tersangka. Selanjutnya dilakukan pemeriksaan barang bukti serta dilengkapi dengan hasil mutlak dari laboratorium forensik. Dalam hal ini, penyidik bertugas untuk memperjelas kronologis terjadinya suatu tindak pidana sehingga dengan langkah tersebut aparat penegak hukum dapat menyelesaikan kasus tindak pidana yang terjadi.

c. Untuk menemukan tersangka

Beberapa tindak pidana merupakan tindak pidana yang dilakukan secara beruntun, misalnya tindak pidana narkotika. Dalam hal ini, bukan hanya pemakainya saja yang dapat menjadi tersangka, namun, kurir atau pengedar, bandar, pemasok, bahkan produsen juga merupakan tersangka yang dapat dijatuhkan hukuman. Oleh karena itu, penyidik dibutuhkan untuk menggali informasi, mencari dan menemukan tersangka-tersangka lainnya.

Beberapa hambatan yang dihadapi oleh penyidik dalam upaya pemeriksaan alat bukti terhadap tindak pidana yaitu:

1) Jarak lokasi laboratorium forensik

Tidak adanya laboratorium forensik di daerah merupakan salah satu hambatan yang dihadapi oleh penyidik dalam pemeriksaan alat bukti. Hingga tahun 2018, Labolatorium Forensik di Indonesia baru berjumlah 8 buah, yaitu 1 Puslabfor Bareskrim Polri di Jakarta), dan 7 Puslabfor Cabang di Medan, Palembang, Semarang, Surabaya, Makasar, Denpasar, dan Balikpapan. Berkaitan dengan hal ini, maka untuk mengirim sampel dan menerima hasil pemeriksaan laboratorium forensik, beberapa daerah membutuhkan waktu paling cepat 4 atau 5 hari sehingga menjadi penghambat diselesaikannya sebuah tindak pidana dengan segera.

2) Terbatasnya biaya operasional 
Proses penyelidikan dan penyidikan dengan oleh penyidik memerlukan biaya yang terkadang tidak sedikit. Kepala Polisi Republik Indonesia, Tito Karnavian mengatakan bahwa salah satu penyebab penanganan perkara tidak maksimal adalah karena anggaran Polri terbatas. Tito Karnavian menganggap anggaran Polri, khususnya di bidang reserse dalam setahun tidak cukup karena penanganan masing-masing kasus berbeda. Ada yang memiliki biaya kecil, ada juga yang butuh anggaran ekstra karena dianggap cukup sulit. ${ }^{16}$

Tito Karnavian mengatakan bahwa dengan sistem anggaran indeks, Polri membagi penanganan perkara dalam empat kategori, yakni kasus sangat sulit, sulit, sedang, dan ringan. Namun, anggaran yang dikeluarkan untuk kasus tertentu tidak bisa diprediksi, karena bisa melebihi yang diperkirakan. Misalnya, kasus penghinaan yang tergolong kasus ringan, anggaran normalnya sekitar Rp 7 juta, Namun, dalam beberapa kasus, penyidik harus mendatangi saksi dari luar kota sehingga butuh biaya ekstra. ${ }^{17}$

3) Kurangnya jumlah sarana dan prasarana yang diperlukan

Kekurangan peralatan yang digunakan untuk melakukan penyelidikan maupun penyidikan untuk mengumpulkan alat bukti. Dalam hal ini misalnya untuk melakukan penyadapan. Tanpa adanya peralatan yang cukup maka dapat mempengaruhi kecepatan serta ketelitian penyidik dalam mengumpulkan alat bukti mengenai suatu tindak pidana.

\section{Penutup}

Peran Laboratorium Forensik Polri sebagai ahli di bidangnya sesuai Pasal 7 ayat (1) huruf h dan Pasal 120 ayat (1) KUHAP dalam pengolahan Tempat Kejadian Perkara (TKP) dengan penerapan metode scientific crime investigation (SCI). Implementasi SCI/Kriminalistik/Forensik dalam olah TKP merupakan jaminan mutu (Quality Assurance) dan kendali mutu (Quality control). Dalam pelaksanaan olah TKP, implementasi tersebut berperan penting terhadap proses menciptakan keyakinan hakim guna penetapan putusan peradilan dan merupakan alat bukti yang sah tidak terbantahkan karena berdasarkan kaidah-kaidah ilmiah.

Beberapa hambatan yang dihadapi oleh penyidik dalam upaya pemeriksaan alat bukti terhadap tindak pidana yaitu: jarak lokasi dari daerah ke Labolatorium Forensik Cabang yang jauh, terbatasnya biaya operasional penyelidikan dan penyidikan, serta kurangnya jumlah sarana dan prasarana yang diperlukan.

\section{Daftar Pustaka}

\section{Buku :}

Abdul Mun'im Idries dan Agung Legowo Tjiptomartono, Penerapan Ilmu Kedokteran Kehakiman dalam Proses Penyidikan, (Jakarta: Karya Unipres, 1982).

Abdussalam, Buku Pintar Forensik (Pembuktian Ilmiah), (Jakarta: Restu Agung, 2006).

\footnotetext{
16 "Kurang Anggaran untuk Tangani Perkara, Polri Ingin Seperti KPK", https://nasional.kompas. com/read/2018/01/03/14344491/kurang-anggaran-untuk-tangani-perkara-polri-ingin-seperti-kpk, diakses tanggal 5 Mei 2018.

${ }^{17}$ Ibid.
} 
Distty Rosa Permanasari Harry Tanto, Fungsi Dan Peran Laboratorium Forensik Dalam Mengungkap Sebab-Sebab Kematian Korban Tindak Pidana Pembunuhan (Studi Pada Laboratorium Forensik Cabang Semarang), Skripsi, Universitas Negeri Semarang, 2011.

H.S. Brahmana, Kriminalistik dan Hukum Pembuktian, (Langsa: LKBH Fakultas Hukum Universitas Samudra, 2014).

Sudarsono, Cara Penyelesaian Karya Ilmiah di Bidang Hukum, edisi revisi, (Yogyakarta: Mitra Kebijakan Tanah, 2006).

Teguh Prihmono, Umar Ma'ruf, dan Sri Endah Wahyuningsih, Peran Laboratorium Forensik Polri Sebagai Pendukung Penyidikan Secara Ilmiah Dalam Sistem Peradilan Pidana Di Indonesia, Jurnal Hukum Khaira Ummah, Vol. 13. No. 1 Maret 2018.

Yulia Monita dan Dheny Wahyudhi, Peranan Dokter Forensik Dalam Pembuktian Perkara Pidana, https://media.neliti.com/media/publications/43243-ID-peranandokter-forensik-dalam-pembuktian-perkara-pidana.pdf, diakses tanggal 5 Mei 2018.

\section{Peraturan Perundang-undangan :}

Undang Undang No. 8 Tahun 1981 tentang Kitab Undang-Undang Hukum Acara Pidana (KUHAP)

Peraturan Kapolri Nomor 10 Tahun 2009 tentang Tata Cara dan Persyaratan Permintaan Pemeriksaan Teknis Kriminalistik Tempat Kejadian Perkara dan Laboratoris Kriminalistik Barang Bukti Kepada Laboratorium Forensik Kepolisian Negara Republik Indonesia.

\section{Sumber Bahan Lainnya :}

la.bo.ra.to.ri.um, https://kbbi.kemdikbud.go.id/entri/laboratorium, diakses tanggal 2 Februari 2017.

fo.ren.sik /forènsik/, https://kbbi.kemdikbud.go.id/entri/forensik, diakses tanggal 2 Februari 2017.

Forensik, Jalan untuk Mengungkap Kasus Pidana, http://www.hukumonline.com/berita/ baca/lt56bb21c48c5ea/forensik--jalan-untuk-mengungkap-kasus-pidana, diakses tanggal 2 Februari 2017

Apa Itu Ilmu Forensik? http://ondigitalforensics.weebly.com/digital-forensics/apa-ituilmu-forensik\#.W6KBdUC4S_Q, diakses tanggal 2 Februari 2017

"Kurang Anggaran untuk Tangani Perkara, Polri Ingin Seperti KPK", https://nasional.kompas. com/read/2018/01/03/14344491/kurang-anggaran-untuktangani-perkara-polri-ingin-seperti-kpk, diakses tanggal 5 Mei 2018. 
Volume 14, Nomor 1, Januari-Juni 2019

Mengenal Laboratorium Forensik Bareskrim Polri, https://www.danielbachrul.com/2015/ 09/mengenal-laboratorium-forensik.htm, diakses tanggal 6 Mei 2018 